\title{
A "Quiet Victory": National Provincial, Gibson Hall, and the Switch from Comprehensive Redevelopment to Urban Preservation in 1960s London
}

\author{
VICTORIA BARNES \\ LUCY NEWTON \\ PETER SCOTT
}

\begin{abstract}
(c) The Author(s), 2020. Published by Cambridge University Press on behalf of the Business History Conference. This is an Open Access article, distributed under the terms of the Creative Commons Attribution-NonCommercialNoDerivatives licence (http://creativecommons.org/licenses/by-nc-nd/4.0/), which permits non-commercial re-use, distribution, and reproduction in any medium, provided the original work is unaltered and is properly cited. The written permission of Cambridge University Press must be obtained for commercial reuse or in order to create a derivative work.
\end{abstract}

doi:10.1017/eso.2020.35

Published online November 16, 2020

Victoria BARNes is a senior research fellow at the Max Planck Instutite for European Legal History, Frankfurt, Germany. She works on the history of business, its form and regulation in law and society. Her recent work can be read in the Journal of Corporation Law, Hastings Business Law Journal, Company Lawyer, and the Journal of Legal History. Contact information: Max-Planck-Institute for European Legal History, Hansaallee 41, Frankfurt am Main, Hesse 60323, Germany. E-mail: barnes@rg.mpg.de.

LuCY NEWTon is professor of business history at Henley Business School, University of Reading. She has published her work on banks and nineteenth-century consumer durables in a variety of business history journals. Her journal article, with Francesca Carnevali, "Pianos for the People," was the winner of the Oxford Journals Article Prize for Best Paper in Enterprise and Society (2013), awarded March 2014. Contact information: University of Reading, Reading, Berkshire, United Kingdom of Great Britain and Northern Ireland. E-mail: l.a.newton@henley.ac.uk.

РетER SCOTT is professor of international business history at the University of Reading's Henley Business School. His research interests include the history of income inequality; living standards; household consumption; the housing sector; the commercial property development and investment market; consumer durables; working hours; and path dependence. His latest monograph, The Market Makers: Creating Mass Markets for Consumer Durables in Inter-war Britain, was published by Oxford University Press in 2017. Contact information: University of Reading, Reading, Berkshire, United Kingdom of Great Britain and Northern Ireland. E-mail: p.m.scott@henley.ac.uk.

We would like to thank the partipicants at the ABH conference in Glasgow in 2017 for their comments on the paper, Grigorij Tschernjawskyj and Marc Di Tommasi for their research assistance, Sally Cholewa at RBS archives and the staff at the London Metropolitan Archives for their help and assistance, and three anonymous referees for their suggestions. Figures 3 and 4 are reproduced with the permission of the National Library of Scotland and 5 and 6 with the permission of RBS. 
The Victorian City of London's financial center expanded and renewed its building infrastructure virtually unimpeded by considerations of urban preservation, conservation, or public opinion. The next phase of massive rebuilding, during the long post-1945 boom, appeared likely to follow the same pattern. However, by the mid-1960s, the freedom of City office owner-occupiers and developers to do as they wished with their buildings had become substantially constrained by rising conservationist sentiment. This paper explores this process through the history of the design, building, and eventual aborted demolition of Gibson Hall, the Bishopsgate headquarters of National Provincial Bank for over a century. This paper charts the life of Gibson Hall, in particular its conception, design, and, ultimately, its attempted redevelopment. We also consider the long-term consequences of the rebalancing between economic and conservation objectives for the nature of British urban redevelopment and the adoption of a "throwaway" business headquarters style-to remove any risk of popular support for preservation.

\section{Introduction}

This paper examines the changing relationship between the functional and symbolic nature of headquarters and other "flagship" buildings from the mid-nineteenth century (when the office building emerged as a distinct business form in Britain) to the late twentieth century and the role of public opinion in mediating this process. This is explored via the history of National Provincial Bank's head office buildings, in the context of the conflicting pressures of development and urban conservation in the City of London and its hinterland.

National Provincial developed what was arguably the finest bank headquarters building of nineteenth-century London-steeped in symbolic architectural imagery that both reflected corporate success and the bank's history and values. However, just over a century later, when National Provincial sought to tear down the building and redevelop the site, demolition was blocked following a determined campaign by conservationists who had been galvanized by the recent destruction of two major London landmarks. This and subsequent campaigns effectively blocked the demolition of buildings considered to be of architectural merit-even if an owner-occupier or developer was eventually successful—as delays and negative publicity might outweigh the gains. Thus, early conservation battles had established the tactics later used 
by groups such as the antiroads movement, summed up in their slogan: "Quiet victories, noisy defeats." 1

The next section outlines the development of National Provincial's Gibson Hall headquarters on Bishopsgate and discusses why its design represented "conspicuous architectural display" in contrast to the discreet architecture of private banking. We then examine the background to its blocked redevelopment a century later, arising from heightened opposition to the destruction of important Victorian buildings-in the wake of two badly handled public sector demolition projects that had provoked a major public backlash. This is followed by a discussion of National Provincial's (and its successor, NatWest's) subsequent efforts to find suitable headquarters accommodation in a commercial property market in which building design was increasingly influenced by pressures to avoid aesthetically appealing buildings that might prove difficult to redevelop following functional obsolescence.

\section{Gibson Hall and the Victorian City}

The second half of the nineteenth century witnessed a huge building wave that transformed the City from a mainly residential area to a purpose-built business district-reflected in a fall in its residential population from 129,000 in 1851 to only 26,000 in 1901, with some 80 percent of the City's physical fabric being rebuilt between 1855 and 1901. ${ }^{3}$ This included six new City railway stations and the remodeling of Lombard Street, at the heart of the City, as a throughfare for banks and insurance companies. ${ }^{4}$ The older residential buildings that were torn down to make room for the new office and warehouse premises were generally not then regarded as distinctive or endangered (being broadly similar to those in other parts of central London). The process thus generated very little controversy.

City bank architecture underwent a similar transformation. Prior to the 1850s, City banking was dominated by the Bank of England and private banks. Private banking typically operated from the residences of the banking families, serving an affluent clientele that valued discretion

${ }^{1}$ Campaign for Better Transport, Campaigner's Guide to Stopping Damaging Roads, brochure, 2014, 20, https://bettertransport.org.uk/sites/default/files/Roads Campaign_Guide_second_edition_Oct2014.pdf .

2 Summerson, "The Victorian Rebuilding of the City of London," 163-185, 170; Black, "Spaces of Capital,” 364.

3 Abramson, Building the Bank of England, 198.

4 Abramson, Building the Bank of England, 198; Booker, Temples of Mammon, 128, 131; Summerson, "The Victorian Rebuilding of the City of London"; Black, "Spaces of Capital," 362. 
and a business culture that "did not need to advertise itself." ${ }^{5}$ Conversely, the new joint stock banks were much more "public," serving a broader customer base and displaying their activities openly in annual reports and shareholders meetings. ${ }^{6}$ The joint stock bankers thus had a very different approach to their new City headquarters buildings, seeking to make bold statements signifying their character, importance, and wealth. This was clearly evident when National Provincial created its new purpose-built head office.

Founded in 1833, National Provincial Bank of England rapidly developed an extensive regional branch network. By the beginning of the 1862, it had over 120 branches and sub-branches in England and Wales outside London. ${ }^{7}$ The majority were acquired through absorbing existing local banking firms and their premises. ${ }^{8}$ A large branch network diversified risk and reduced any adverse impacts from local economic shocks. National Provincial was the only British bank that aimed to cover all of England and Wales but did not offer banking and financial services in London-legislation protecting the Bank of England excluded any joint stock bank issuing notes from operating within a sixty-five-mile radius of the capital. National Provincial had a presence in London, but it served merely as its administrative unit-a central base for governance from which the branch network was supervised. In 1862, National Provincial decided to begin lending and taking deposits from its head office, but as a consequence it had to cease issuing its own banknotes. However, this gave them access the metropolis's wealthy customers, the City's financial services market, and lucrative global markets. ${ }^{9}$

To generate new customers and facilitate physical financial transactions, a distinctive new building was needed. From the nineteenth century, retail banks typically sought large and grandly decorated buildings, in central locations, projecting reliability, stability, and success through their templelike, historic, and age-old imagery, providing a strong, consistent brand image. ${ }^{10}$ Bank headquarters were built to convey "symbolic capital," a concept taken from Bourdieu and his

5 Summerson, "The Victorian Rebuilding of the City of London," 163-185, 168; Black, "Spaces of Capital," 356.

${ }^{6}$ Black, "Spaces of Capital," 354; Cottrell and Newton, "Banking Liberalization in England and Wales, 1826-1844”; Orbell, Turton, and Pressnell, British Banking, 4-5.

7 Barnes and Newton, "How Far Does the Apple Fall from the Tree?" 447-473.

8 Reed, National Westminster Bank: A Short History, 11.

9 The Gentleman's magazine, 1868, 545; The Bankers' Magazine, 1865, 852-853.

${ }^{10}$ Schultz and Hatch, "The Cycles of Corporate Branding," 6-26; Suddaby, Foster, and Trank, "Rhetorical History as a Source of Competitive Advantage"; Barnes and Newton, "Symbolism in Bank Marketing and Architecture," 213-244. 
studies of architectural aesthetics. ${ }^{11}$ Likewise, Dovey has emphasized the importance of aesthetics in cities as a means to provide companies with an identity and competitive distinctiveness, using corporate architecture to denote power, status, and stability. ${ }^{12}$ Those at National Provincial used its new head office to send particular signals to customers, competitors, and the wider community. As a joint stock bank, National Provincial was a relatively new entrant to the City of London. Joint stock banks had entered London in direct opposition to existing private banks and the Bank of England, both of which resented these new upstarts. ${ }^{13}$

Joint stock banks reacted by building much grander and distinctive head office buildings than the private banks, to signify their financial strength, probity, openness, and trustworthiness. As Black highlights, the new joint stock banks "were involved in the production of new symbolic spaces and sought to create a distinct identity for a new and more public form of the money economy." ${ }^{14}$ Joint stock banks also faced vigorous competition from their counterparts: four joint stock banks were established in London in the 1830s; three more between 1840 and 1855; and a further eight in the 1860s. ${ }^{15}$

National Provincial responded by building a head office that outshone its competitors. Its location on Bishopsgate, just around the corner from Threadneedle Street, although not being quite "in the inner sanctum of banking," was nevertheless in the heart of the City and showed that National Provincial meant business. ${ }^{16}$ Plans were initiated in 1862, and in 1864 their existing premises at 112 Bishopsgate, which were in a poor state of repair, were demolished to make room for it. ${ }^{17}$

National Provincial wanted a grand new head office to symbolize its status as a major, successful bank. They appointed John Gibson (18171892), a former pupil of Sir Charles Barry, who had become popular with the business elite when he won the competition to design the National Bank of Scotland in Glasgow in 1844, which opened in 1849 to widespread praise. ${ }^{18} \mathrm{He}$ went on to design the headquarters of the Imperial Insurance Office on Threadneedle Street and a series of

11 Black, "Spaces of Capital," 352.

12 Dovey, "Corporate Towers and Symbolic Capital," 173-178.

13 Black, "Spaces of Capital," 354.

14 Ibid., 362.

15 Orbell, Turton, and Pressnell, British Banking, 51, 71, 142, 149-150, 159160, 185, 287-288, 343-354, 460, 513-514.

${ }^{16}$ Summerson, "The Victorian Rebuilding of the City of London," 163-185, 170; Black, "Spaces of Capital," 355.

17 Private Minute Books of the Court of Directors of National Provincial Bank of England, December 10, 1861, RBS Group Archive [hereafter RBSGA], NAT/934/1.

18 Black, "National Provincial Bank Building," 65; Booker, Temples of Mammon, 71-75. 
country homes. ${ }^{19}$ Gibson maintained a successful relationship with National Provincial, receiving forty further commissions for branches offices. ${ }^{20}$ He was recognized with the award of the Gold Medal of the Royal Institute of British Architects in 1890. ${ }^{21}$ Gibson Hall remains his most famous work. ${ }^{22}$

New bank and insurance headquarters typically included rentable office space on the upper levels, to recoup some of the cost of prime sites, create imposing structures, and facilitate future expansion. ${ }^{23}$ National Provincial rejected this approach in favor of a massive classical single-story headquarters that arguably put even the Bank of England in the shade. Its exterior comprised a series of triumphal arches topped with statues, enclosing a Corinthian hall supporting three glass domesan almost literal "temple of mammon." ${ }^{44}$ This clearly did not maximize the rental potential of the building plot but instead created a huge banking hall that remains one of Victorian London's most glaring examples of "conspicuous architectural display" (by being economically "wasteful" in using a substantial prime site mainly as a banking hall).

When the new premises were unveiled, onlookers and London's popular press reacted with interest and praise for Gibson's design and classical motifs. The showpiece was the banking hall, shown in Figure 1. The leading architectural trade journal the Builder gave a generally positive review. Gibson had admitted that there had been some difficulty in construction and in connecting the building to adjoining properties, creating an asymmetrical hall. Nevertheless, it praised the finish and noted the Roman connotations with the varied pillars and columns, which were "of a strict Corinthian order." ${ }^{25}$ Karl Baedeker's authoritative tourist guidebook (which, ironically, was used by the Luftwaffe to plan bombing raids on several historic British cities) described the structure as "beautiful, in Byzantine-Roman style, richly decorated hall with polished granite columns and polychromatic decoration."26

London and Westminster Bank had built the first joint stock bank head office in London in the 1830s. ${ }^{27}$ Summerson noted that, although this building's façade was “discretion itself," Gibson Hall was, by contrast, the "most exciting, and perhaps really the queen of all the City

\footnotetext{
19 Black, "National Provincial Bank Building," 65.

${ }^{20}$ Booker, Temples of Mammon, 155-162; Black, "National Provincial Bank Building."

21 Black, "National Provincial Bank Building," 65.

22 Waterhouse and Elliott, "Gibson, John."

${ }^{23}$ Black, "Spaces of Capital," 362-363; Summerson, "The Victorian Rebuilding of the City of London," 163-185, 164.

24 Black, "Spaces of Capital," 370.

25 The Builder, 1865, 901.

${ }^{26}$ Baedeker, London Und Umgebungen, 103.

27 Black, "Spaces of Capital," 358-361.
} 


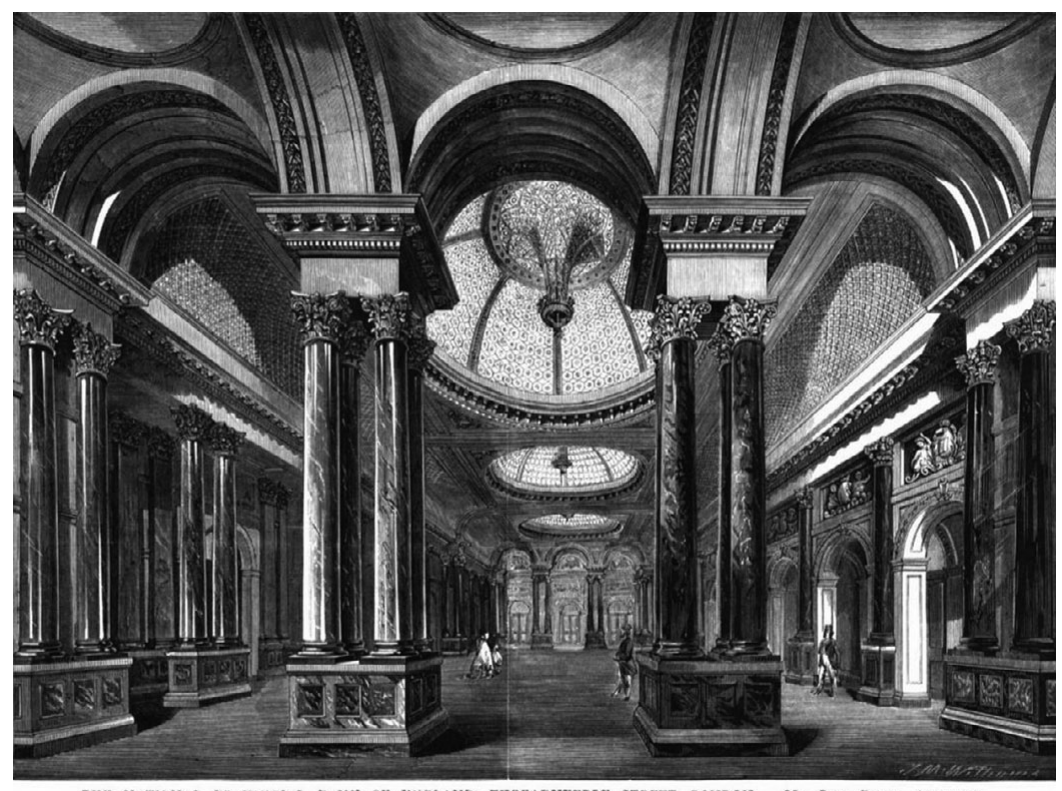

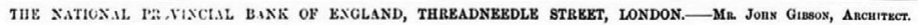

Figure 1 The banking hall (The Builder, 1865, 835).

banks since Soane." ${ }^{28}$ Ward-Jackson summarizes Gibson Hall as follows: "This, the most extravagant of the City's Victorian joint stock banks, makes its mark principally through the profusion of its sculptural adornments." 29

The building's exterior, shown in Figure 2, echoed artwork from the Greek and Roman periods, commended by both contemporaries and later commentators. ${ }^{30}$ This conveyed a very specific symbolism, designed to reflect the bank's provincial roots, augmented by further additions to the artwork over the building's banking lifetime. The statues and relief panels represented images of regional commerce and industry, reflecting its provincial roots and distinctiveness as a national bank. For example, Wales was represented by a statue of Saint David, along with an old harper and a miner with his pickaxe; the metal trades of Birmingham were represented by a female figure holding a hammer and anvil; and Manchester was represented by a female figure supported by a seated figure holding raw cotton. ${ }^{31}$ The wealth of the bank was made obvious, as Kynaston noted: “John Gibson's magnificent classical banking hall ... resplendent with Corinthian columns and

${ }^{28}$ Summerson, “The Victorian Rebuilding of the City of London,” 169, 170.

29 Ward-Jackson, Public Sculpture of the City of London, 35.

30 Stamp and Amery, Victorian Buildings of London, 75.

31 Illustrated London News, January 20 1866, 57. Ward-Jackson, Public Sculpture of the City of London, 37. 


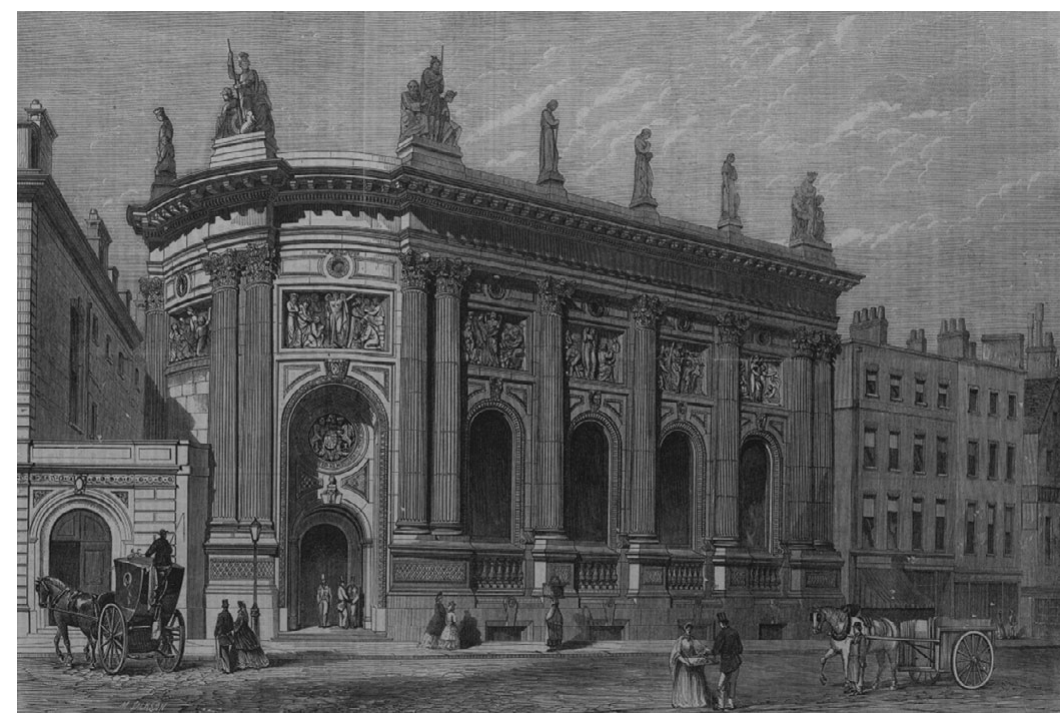

Figure 2 National Provincial Bank of England, at the corner of ThreadneedleStreet and Bishopsgate-Street. (Illustrated London News, January 20 1866, 57).

marble pillars, would have eased the doubts of even the most neurotic depositors.”32

The interwar era witnessed a sustained transformation of London's central business district, as the Bank of England and other major banking institutions rebuilt their headquarters in the heart of the City. ${ }^{33}$ However, as Figures 3 and 4 illustrate, in the 1950s Gibson Hall was still close to the heart of the City, adjacent to the Bank of England, the Stock Exchange, the Royal Exchange, and other bank offices to the left. Banks were also positioned to the right of Gibson Hall, together with other financial organizations, exchanges, and warehouses.

More drastic rebuilding was necessary following World War Two, when "one-third of the City lay in ruins." 34 Tensions arose. Planners wished to retain the seventeenth-century scale of the City but recognized the need for progress and expansion. This included some relaxation of the previously strict controls on high-rise building in the City. ${ }^{35}$ National Provincial also looked to the future, seeking a larger, modern building suitable for postwar office technology and standards of comfort. Unfortunately for National Provincial, its attempts to address this problem were particularly ill-timed.

\footnotetext{
${ }^{32}$ Kynaston, The City of London, 226, 1, 244-245.

33 Black, "Rebuilding 'The Heart of the Empire,"” 593.

${ }^{34}$ Kynaston, The City of London, vol. 4, 127.

35 Ibid., 128-129.
} 


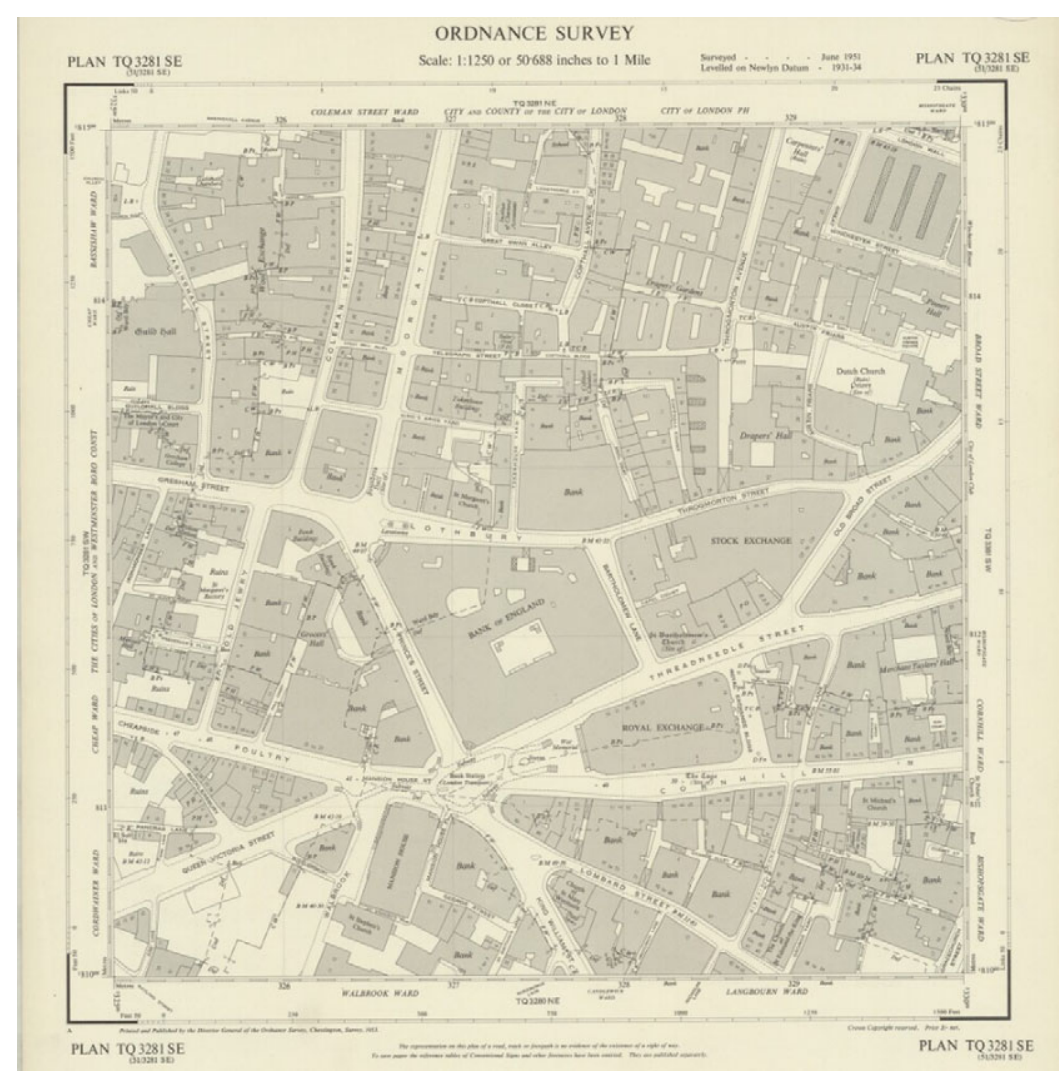

Figure 3 Ordnance Survey Map 1951 TQ 3281.

\section{Postwar City Modernization and the Attempted Redevelopment of Gibson Hall}

In the early 1960s, National Provincial proposed to replace Gibson Hall with a new skyscraper, reflecting contemporary building trends and the rising headquarters space requirements of one of Britain's "Big Five" banks. National Provincial had expanded considerably since the 1860s, following the general trend of intensive merger activity among the English clearing banks from the 1870s to 1918. By 1918, when the merger wave subsided, National Provincial had over seven hundred offices spread throughout England and Wales. Branch extension continued between the wars and after 1945. By 1946, National Provincial had 12.8 percent market share of UK banking deposits, which declined slightly to 11.8 percent in 1961 but then increased to 14.5 percent in 1962 on its merger with District Bank. In terms of advances, its market share had fallen from 15 percent in 1946 to 12.3 percent in 1961. 


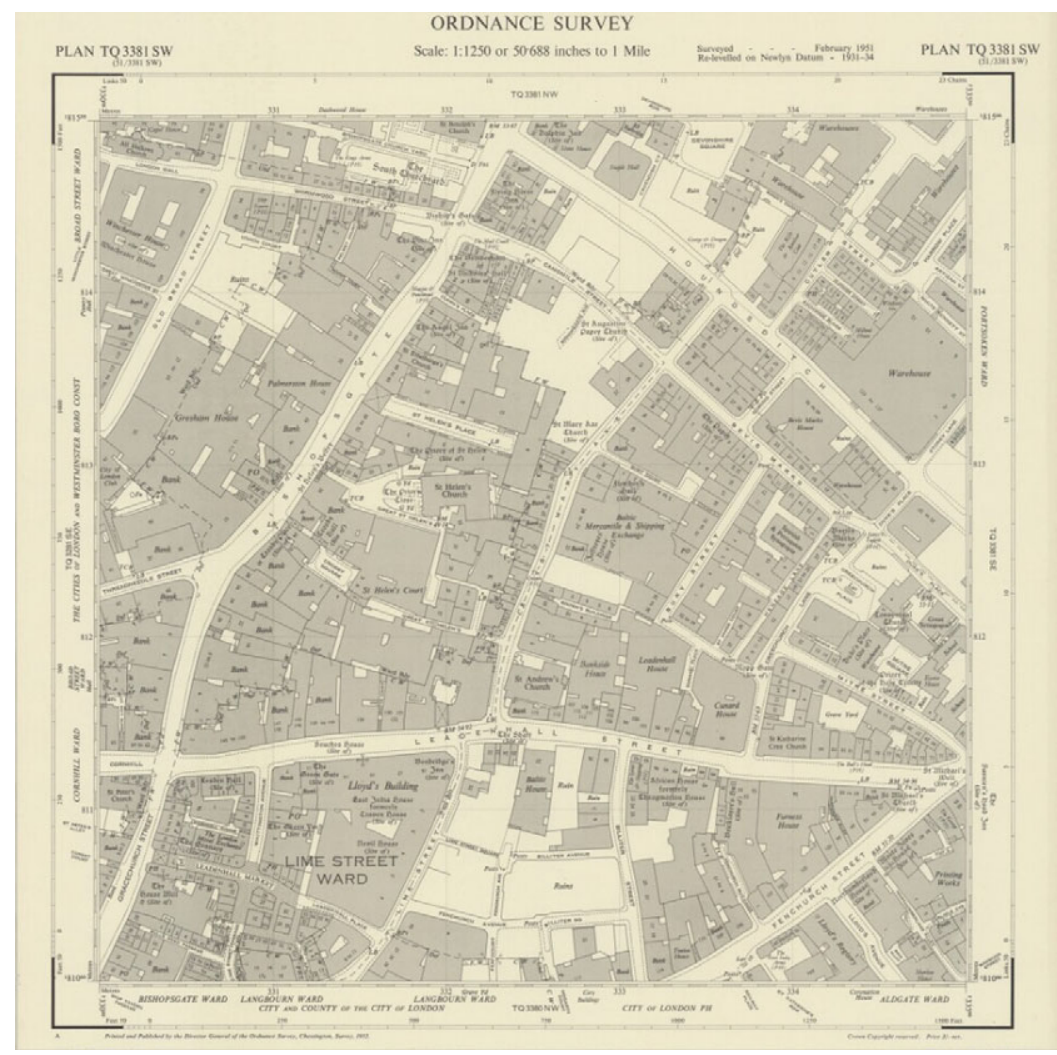

Figure 4 Ordnance Survey Map 1951 TQ 3381.

Therefore, it was both failing to keep up with its competitors in terms of organic growth and remaining the smallest of the "Big Five."36

National Provincial had been planning a new headquarters long before the formal announcements were made in 1963. An adjacent building, Gresham House, was purchased in 1959 for $£ 3.3$ million, though it took another six years to empty the building, and cost the bank a further $£ 250,000$ in compensation to the tenants. ${ }^{37}$ The new headquarters development would require the demolition of Gibson Hall, as well as Gresham House and some surrounding buildings, such as the City of London Club on Broad Street and Fountain Court. ${ }^{38} \mathrm{~A}$ skyscraper marked a radical departure from the classical style of Gibson

36 Ackrill and Hannah, Barclays, 154, 183.

37 Papers concerning the proposed rebuilding of the Bishopsgate head office of National Provincial Bank Ltd and consequent plans for the NatWest Tower, Intelligence Department, excerpt from the Sunday Times Business News, Charles Raw, “The Bank Men and a Ban,” marked August 22, 1965, RBSGA, NAT/348.

${ }^{38}$ Papers concerning the proposed rebuilding of the Bishopsgate head office of National Provincial Bank Ltd and consequent plans for the NatWest Tower, 
Hall, which would free National Provincial from the widespread problem of bank premises that were "victims of their magnificent but constricting architectural history." 39

During the era of "white heat" and technological change in the 1960s, ${ }^{40}$ National Provincial's Victorian head office symbolized an identity the bank no longer wished to embody. Gibson Hall captured the bank exactly how it feared being recognized. The ancient monuments suggested that National Provincial was stuck in the past-classical and opulent, yet obsolete. The bank looked to distance itself from this symbolism and develop a replacement head office, which reflected how it wanted to be seen. The new tower would communicate its progress and ability to keep pace with change and competition, symbolizing the future rather than the past. No longer was banking the preserve of a wealthy elite, as in the days of private banking, or even of a broader upper-middle class, as in the 1860s, but of a more democratic, corporate culture, housed in open, glass covered buildings.

As well as appearing anachronistic, Gibson Hall's artistic symbolism had lost its original significance. Asserting regional or provincial roots no longer made sense when the "Big Five" retail banks each possessed national branch networks. Furthermore, the symbolic language had largely lost its meaning. The Daily Telegraph believed that the sculptures "represented ... [the bank's] role in society," including "agriculture, commerce, shipping, the arts and sport," while misidentifying one of the female figures as a woman "sitting down and holding a cricket bat" (possibly reflecting wear to the statues that had eroded some of their original detail). ${ }^{41}$ As those at the bank saved this clipping but did not challenge the mistake, we can assume they perceived this

Intelligence Department, excerpt from the Investors Chronicle, February 21, 1964, and Evening Standard, February 18, 1964, RBSGA, NAT/348.

${ }^{39}$ Newman, Financial Marketing and Communications, 317. There was also an incentive to demolish old buildings and construct new offices due to a regulation known as the Third Schedule of the Town and Country Panning Act of 1947, which allowed a building to be enlarged by 10 percent. The aim had been to allow property owners to make improvements to existing buildings. Rather, developers used the Third Schedule to demolish old buildings and build new, larger offices. Marriott, The Property Boom, 170-171; Calder, Raw Concrete, 211-212.

40 Saumarez Smith notes the commitment of both the Conservative government of 1959-1964 and the Labour government of 1964-1966 to modernist planning philosophy. Smith, "Central Government and Town-Centre Redevelopment in Britain," 217-244.

${ }^{41}$ The statue, which depicted England, was perhaps the easiest to identify as Saint George and the Dragon and Britannia, with wreath and shield bearing the lion's head. These remain popular symbols. See Papers concerning the proposed rebuilding of the Bishopsgate head office of National Provincial Bank Ltd and consequent plans for the NatWest Tower, Intelligence Department, Daily Telegraph, "Lady Cricketer, 1865," n.d, RBSGA, NAT/348. 
misstatement to be true (or irrelevant in an era when classical imagery was becoming a dead language to most people). Even the bank staff failed to understand imagery, which had once been common currency. For example, no one now knew who the bust of Robertson depicted. It was intended to serve as a record and as a memento of the bank's success; it had once been central to their organizational memory. ${ }^{42}$

However, the main rationale for redevelopment was that its headquarters were no longer fit for its purpose. In a letter submitted to the public inquiry, the bank's solicitors wrote that 13 Bishopsgate "is ill-adapted for any practicable function, is hopelessly inconvenient, presents great problems of maintenance, is depressing, obsolete and unnecessary." 43 Reports emphasized that the bank had grown substantially over the last one hundred years, expanding from 122 to 2,220 branches. When first constructed, one hundred employees worked in the London office. This figure had grown to 1,866, excluding nonclerical staff. ${ }^{44}$ Technology and computerization had enhanced the efficiency of banks, but when Gibson Hall was erected "there were no telephones, no typewriters, no adding machines, no bookkeeping machines." ${ }^{45}$ In addition to its administrative functions, the branch itself had serious disadvantages, as it was apparently "almost impossible in a building of this type to reduce the noise level to reasonable proportions and the banking hall is difficult to light, to heat, to ventilate and to keep clean." 46

In sum, those at National Provincial considered that they had an overwhelming case for redevelopment. What they did not appear to have appreciated was that between the late 1950s, when redevelopment was first planned, and 1963, when the public inquiry was held, public attitudes toward the destruction of historic buildings had moved decisively in favor of preservation.

42 Daniel Robertson was the first General Manager of the National Provincial Bank of England, serving from 1833 to 1863. Information recorded in Photographs of staff at 15 Bishopsgate office of National Provincial Bank of England Ltd. c. 19001950s, RBSGA, NW/B430/5.

${ }^{43}$ Papers concerning the proposed rebuilding of the Bishopsgate head office of National Provincial Bank Ltd and consequent plans for the NatWest Tower. Letter from Solicitors of National Provincial Bank in the matter of the Preservation order, Grounds of Objection, dated October 10, 1963, RBSGA, NAT/348.

${ }^{44}$ Papers concerning the proposed rebuilding of the Bishopsgate head office of National Provincial Bank Ltd and consequent plans for the NatWest Tower, "Application for Confirmation of Preservation Orders and Appeal by National Provincial Bank Limited," appeal held February 18-21 and March 2-4, 1964, 14, RBSGA, NAT/ 348.

45 Papers concerning the proposed rebuilding of the Bishopsgate head office of National Provincial Bank Ltd and consequent plans for the NatWest Tower, untitled and dated official document from National Provincial relating to the public inquiry, RBSGA, NAT/348.

46 Ibid. 


\section{The Rise of Urban Conservation in Postwar Britain}

Britain's building conservation movement can be traced back to the foundation of the Society for the Protection of Ancient Buildings (SPAB) by William Morris in 1877. The London County Council (LCC) was an early advocate, being the first council to gain general powers to preserve buildings (by purchasing them, with the agreement of the owner) as early as $1898 .{ }^{47}$ Indeed, the City had witnessed some of the most important conservation victories of the early twentieth century, including frustrating the Bishop of London's 1919 initiative to close and sell the sites of nineteen City churches, some designed by Wren or Hawksmoor, which was eventually blocked by Parliament in 1926, following a petition from the Corporation of London. ${ }^{48}$

In 1935, the Georgian Group was formed as an offshoot of SPAB. However, the conservation movement was relatively dormant during the late 1940s and early 1950s, partly owing to the fact that scarce building resources were focused on repairs or reconstruction around bomb sites. Wartime bombing had destroyed 225 acres, or one third, of the City, and as government building licenses prioritized such sites, the proportion of redevelopments involving demolishing structurally sound buildings was small.

The 1944 and 1947 Town and Country Planning Acts had established a system for listing buildings of special historical or architectural importance, though this activity was initially a very low priority for the fledgling Ministry of Town and Country Planning or successive ministers, while urban preservation also appears to have commanded relatively little public support during the first postwar decade. However, following the abolition of government building license controls in November 1954, the pace of redevelopment accelerated, with a growing proportion of projects involving the demolition of existing buildings. From 1948-1956 planning permissions for offices in central London averaged 3,544,000 square feet. However, this rose to 4,753,000 in 1957 and 4,796,000 in 1961.

Moreover, the supply of well-located bomb sites was drying up, leading developers to increasingly focus on demolishing those buildings that had survived the Blitz. ${ }^{49}$ Given the wartime destruction of many important buildings, especially in the City, further destruction of such buildings was likely to stoke controversy and oppositionsomething that the government failed to take account of until its

\footnotetext{
47 Earl, "London Government,” 66.

48 Stamp, "The Art of Keeping One Jump Ahead," 79.

49 Marriott, The Property Boom, 66, 170-171.
} 
mishandling of two particularly sensitive developments transformed a latent public concern into a social movement.

Preservation activity had previously focused on Georgian or earlier buildings. Indeed, it was not until the Ministry's 1960 annual report that mention was made that their Advisory Committee had been considering the question of listing nineteenth- and twentieth-century buildings-reflecting an awakening public sentiment that Victorian architecture (which had traditionally been widely reviled by the artistic elite) was also an important part of Britain's heritage. ${ }^{50}$ Such buildings were to be at the forefront of battles between the developers and preservationists during the early 1960s.

One early skirmish involved the demolition of the St. James Theatre by the developer Felix Fenston in 1957, to make way for an office block. The actress Vivien Leigh led the preservationists in a well-publicized campaign, which included her interrupting the House of Lords debate on the theater (prompting her removal by Black Rod) and a protest rally in Trafalgar Square. ${ }^{51}$ The campaign failed but widened and strengthened opposition to such redevelopment. The year 1957 saw the launch of the Civic Trust as an urban equivalent of the Council for the Protection of Rural England, while a year later the Victorian Society was established and went on to play a leading role in preservation battles. ${ }^{52}$

Yet it was only in the early 1960s that the preservation movement gained substantial support, following two noisy defeats of campaigns to save notable London landmarks. Ironically, both were public sector transport projects, whose clumsy handling by government officials and ministers played no small role in empowering the preservation lobby. ${ }^{53}$ The first was the Coal Exchange on Lower Thames Street, one of the City's former speciality trading markets. Despite being Grade II listed, the Exchange was demolished in November 1962 as part of a road-widening scheme.

The redevelopment of Euston Station prompted even greater public uproar, regarding the destruction of its Euston Arch entranceway (again

50 Delafons, Politics and Preservation, 62, 82; Stamp, "The Art of Keeping One Jump Ahead," 86.

51 Marriott, The Property Boom, 6.

52 Scott, The Property Masters, 144. The deputy chair of the Victorian Society, Mr. Brandon-Jones, attended the public inquiry into the preservation of Gibson Hall on February 18, 1964, and later submitted a report from the society. London and Middlesex Archaeological Society and the London Society also offered letters of support for the preservation of Gibson Hall to be submitted to the same inquiry dated February 10, 1964, and February 14, 1964, respectively. RBSGA, NAT/348, Papers concerning the proposed rebuilding of the Bishopsgate head office of National Provincial Bank Ltd and consequent plans for the NatWest Tower.

${ }^{53}$ Delafons, Politics and Preservation, 83; Abramson, Obsolescence: An Architectural History, 111. 
Grade II listed). The LCC, while accepting the demolition of the main building, suggested that the arch could be reerected, but a cashstrapped British Transport Commission refused to cover the cost. The Euston Arch was particularly notorious, in that it could easily have been rebuilt to front the new Euston Station at a cost estimated by the government-in defending their action—at $£ 190,000$, which could have been more than offset by the development of offices above the station. Even the demolition contractor, Frank Venturi, was said to be shocked at the decision and saved some of the masonry blocks, which he transported to the garden of his country home. ${ }^{54}$ The government's parsimony reflected Treasury pressures to keep building costs down, part of a broader "stop-go" policy of restricting building and public investment expenditure in order to avoid inflationary pressure on sterling and thereby accelerate the reestablishment of London as a leading financial center. ${ }^{55}$ However, in this instance the policy spectacularly backfired, with long-term negative implications for developers' freedom to modernize the City's physical infrastructure.

As John Earl has noted, "Preservation movements commonly make progress following the shock of some single traumatic act of destruction." 56 The Coal Exchange and Euston Arch demolitions had a galvanizing effect on the preservation movement, similar to that of the destruction of New York's iconic Pennsylvania Station-though British policy makers reacted much more rapidly to the change in public opinion than their American counterparts. The two noisy defeats of 1961-1962 were followed by a great number of "quiet" (sometimes silent) victories in which buildings were often saved before any preservation protests could build up a head of steam. Indeed, it has been argued that Britain did not experience any demolitions of buildings of similar historic importance for the rest of the century. ${ }^{57}$ More than six hundred buildings were successfully protected by the LCC under pre-1968 legislation, arguably the most high profile of which was Gibson Hall, involving a three-week public inquiry in the face of an extremely economically important and well-connected owneroccupier, which received considerable support from its friends in the national press. ${ }^{58}$

\footnotetext{
${ }^{54}$ Esher, A Broken Wave, 139-140; Stamp, "The Art of Keeping One Jump Ahead," 90; Delafons, Politics and Preservation, 84.

${ }^{55}$ See Scott and Walker, “'Stop-Go' Policy and the Restriction of PostWar British House-Building,” 716-737.

56 Earl, "London Government," 58.

57 Delafons, Politics and Preservation, 82-83.

58 Earl, "London Government," 72.
} 


\section{The Rejection of National Provincial's Plans}

Following National Provincial's announcement, and after some consultation between the City Corporation and LCC (who had the final say as the relevant local authority), preservation orders were made upon Gibson Hall and the City of London Club. The LCC sent the Corporation of London a letter confirming that, under the Town and Country Planning Act of 1962, the head office of National Provincial was subject to a preservation order by which the building "shall not without the consent of the authority [LCC] be demolished, or altered or extended by any works which affect the structure or architectural detail of any part of the exterior or interior of the building." ${ }^{59}$ A statement of the grounds for order noted its external and internal architectural importance:

Within the rigidly architectural scheme of the façade, the elements are treated with an outstanding elaboration of detail and wealth of carving which exemplified the Victorian striving for magnificence at its finest effect and yet still under complete control within the classical framework.... The masterly handling of the elements of this face and the superlative quality of the detail make it amongst the finest buildings of its kind to be found anywhere in the country. ${ }^{60}$

Meanwhile, the interior was described as "one of the most ambitious and finest banking halls of its date to be found in the City." 61

The orders halted further development and prevented the destruction of the buildings. A public inquiry was held in February 1964 to establish whether the government would allow National Provincial to proceed with its plan to tear down Gibson Hall and build a tower on the empty site. As the inquiry involved high profile legal counsel and government officials, it naturally attracted much attention and press coverage.

The London financial and business press generally supported National Provincial. The Daily Telegraph noted that the bank claimed "correctly, that in a mechanised age it has become too noisy and inconvenient." 62 The Financial Times alluded further to the general benefit

59 Building Preservation Orders: certified copies of orders and maps, 1963, London Metropolitan Archives [hereafter LMA], COL/PL/06/05/006. See also National Provincial Bank, 15 Bishopsgate and City of London Club, Old Broad Street, The National Archives, HLG 126/870 (1963).

${ }^{60}$ Building Preservation Orders: certified copies of orders and maps, 1963, LMA, COL/PL/06/05/006.

61 Ibid.

${ }^{62}$ Papers concerning the proposed rebuilding of the Bishopsgate head office of National Provincial Bank Ltd and consequent plans for the NatWest Tower, Intelligence Department, [hereafter RBSGA, NAT/348, Intelligence Dept.] Daily Telegraph, February 24, 1964, RBSGA, NAT/348. 
of demolishing 13 Bishopsgate as being "much to the advantage of the City that the piecemeal redevelopment of the individual sites should be replaced by developments which, because of their size, can provide much freer circulation on the ground." ${ }^{63}$ Congestion was a large problem; deliveries of bullion had caused serious delays on nearby roads. ${ }^{64}$ Other newspapers reported that the building itself was dangerous as the statues had begun to crumble and fall into the street below. ${ }^{65}$ The Financial Times questioned whether they "should be persevered at the cost of a substantial public improvement." 66

The Times noted that LCC officials, such as Michael Mann, saw value in preserving a building that constituted "an outstanding example of high-Victorian classical design and was of monumental grandeur seldom found in English Architecture." 67 Giving evidence alongside the Victorian Society and other historical groups, the LCC stood firm and asserted that the building should stay. A few months later and after some deliberation, H. A. Hamilton, the inspector responsible for determining the outcome of the inquiry, ruled in favor of the bank, arguing that the development was important to the national economy ${ }^{68}$ However, his decision was overruled by the Minister for Housing and Local Government, Keith Joseph (1918-1994). Possibly swayed by public opinion (in the run-up to the 1964 general election), he expressed himself to be "most unwilling to concur with ... [Gibson Hall's] destruction." 69 The banking hall should be preserved as "a fine building and good example of Victorian classic bank architecture."70 The preservation orders thus stood firmly in place.

Much of the evidence presented at the Gibson Hall public inquiry supported National Provincial's decision to demolish and rebuild. The bank's staff stated that they disliked working there as the building had "a long and draughty corridor connecting the two parts of this labyrinthine conglomeration of buildings... It is popularly known, or should I

${ }^{63}$ Intelligence Dept., Financial Times, February 14, 1964, RBSGA, NAT/348.

${ }^{64}$ Intelligence Dept., Financial Times, February 28, 1964, RBSGA, NAT/348.

65 Intelligence Dept., The Statist, August 14, 1964, RBSGA, NAT/348.

${ }^{66}$ Intelligence Dept., Financial Times, "L.C.C. Wants to Preserve Two City Buildings,” February 14, 1964, RBSGA, NAT/348.

67 Intelligence Dept., The Times, “Tussle Over Large City Site,” February 19, 1964, RBSGA, NAT/348.

${ }^{68}$ Intelligence Dept., City Press, "Bank Architect Cramped by Minister's Decision,” August 14, 1964, RBSGA, NAT/348. See also “'Classic’ Bank Building to Be Preserved," Guardian, August 8, 1964.

69 Intelligence Dept., City Press, "Bank Architect Cramped by Minister's Decision,” August 14, 1964, RBSGA, NAT/348.

${ }^{70}$ Intelligence Dept., Evening Standard, "Sir Keith Saves City Banking Hall," August 7, 1964, RBSGA, NAT/348. 
say unpopularly known, as 'pneumonia corridor."”71 It is not known to what extent, if any, the staff were "coached" before presenting their evidence, though their views reflected common perceptions that modern offices offered a superior work environment; that they were not dependent on natural light and air from tall windows, avoided lofty ceilings that made heating more difficult, and replaced numerous passages and stairways with larger, open, office spaces. ${ }^{72}$

Despite failing to remember parts of the building's history, those at the bank purported to be well-informed about architectural history more generally. Indeed, they used it "creatively" to argue the case for demolition. They employed a quote from leading Victorian art critic John Ruskin to support claims that the building had ceased to be functional: "We require of buildings two kinds of goodness: first, doing their practical duty well and, secondly, that they be graceful and pleasing in doing it."73 As the bank's spokesman had announced that the building was no longer fit for its function as a head office, or even as a branch, it failed to perform its practical duty. Following Ruskin's logic, National Provincial argued that Gibson Hall ceased to be a "good" building even in the eyes of the Victorian establishment.

Bank witnesses marshalled other historic figures to support their cause, often making arguments that might politely be described as "disingenuous." For example, National Provincial argued that Gibson, were he still alive, would have supported demolition, as he would have recognized that every building had a finite lifespan and should not be preserved in perpetuity: "[The a]rchitect who designed the present banking hall a century ago would have been surprised" at the suggestion that "a single-story building in such a prominent position" should be a "permanent" location for the bank. ${ }^{74}$ Gibson had not made any statement at the time of its construction to support or reject this idea, nor was this evidence based on Gibson's views. Tellingly, in this testimony, John Gibson was not identified by name but rather as the

${ }^{71}$ Papers concerning the proposed rebuilding of the Bishopsgate head office of National Provincial Bank Ltd and consequent plans for the NatWest Tower, “'Pneumonia Corridor' at N.P. Bank Headquarters," Financial Times, February 26, 1964, RBSGA, NAT/348.

72 Marriott, The Property Boom, 171; Calder, Raw Concrete, 211.

${ }^{73}$ Papers concerning the proposed rebuilding of the Bishopsgate head office of National Provincial Bank Ltd and consequent plans for the NatWest Tower, untitled and dated official document from National Provincial relating to the public inquiry, "Application for Confirmation of Preservation Orders and Appeal by National Provincial Bank Limited,” appeal held February 18-21 and March 2-4, 1964, 15, RBSGA, NAT/348; Brooks, John Ruskin and Victorian Architecture.

${ }^{74}$ Papers concerning the proposed rebuilding of the Bishopsgate head office of National Provincial Bank Ltd and consequent plans for the NatWest Tower, untitled and dated official document from National Provincial relating to the public inquiry, RBSGA, NAT/348. 
"Architect." This neutralized the impact of his personal reputation as the most celebrated mid-Victorian bank architect ${ }^{75}$ as an argument for preservation (not to mention the strong reputations of his collaborators Baron Marochetti and John Hancock). Later in the public inquiry, Derek Walker-Smith, a Conservative MP and QC drafted in by Natonal Provincial, denigrated Gibson by referring to him as "only a good run-ofthe-mill architect"- despite the wealth of eminent opinion to the contrary. ${ }^{76}$

The papers neglected to mention the staff members commemorated by the sculptures and plaques-their deaths had been so long ago that their personalities had been forgotten. Furthermore, banks had lost interest in applying a personal touch and integrating staff members into the community. Vik used interviews with United Kingdom bank branch managers to show that, with the onset of computerization and target-driven performance, ${ }^{77}$ they felt deskilled, disempowered, and subservient to computerized decision-making. Thus, he believes that these changes brought about a new era of depersonalized banking.

Certainly, the bank's proposed new building did not emphasize its personnel, uniqueness, or personality—it resembled most other office buildings of the time. Their prospective new skyscraper headquarters for the site (shown in Figure 5) was a glass building devoid of insignias or emblems. Whereas pre-1940 U.S. skyscrapers sometimes contained such symbols—a classic example being the Chrysler Building (1929)— mid-century modernism rejected such ornamentation, a view warmly endorsed by cost-conscious developers who were attracted to a watered-down version of modernism on cost and functionality grounds. "Faceless" buildings were also easier to sell if they became surplus to requirements and avoided any risk of being viewed as having distinctive architectural significance (that might delay or prevent eventual redevelopment). ${ }^{78}$

Although the skyscraper had become the model City office, National Provincial's new head office was not a simple design. This thirty-threestory tower reaching 450 feet high would have dominated the skyline as the City's largest building, casting a significant shadow. ${ }^{79}$ This project signified the bank's wealth and power as much as Gibson Hall had to onlookers in the nineteenth century. The difference here was not so much about moving away from suggestions of affluence but to distinguish between modern and historical symbolism: modern skyscrapers

75 Black, "Spaces of Capital," 368.

${ }^{76}$ Intelligence Dept., The Times, "Tussle Over Large City Site," February 19, 1964, RBSGA, NAT/348.

77 Vik, “'The Computer Says No,"” 231-249.

78 Frandsen et al., "From Money Storage to Money Store," 697-698.

${ }^{79}$ Intelligence Dept., City Press, February 21, 1964, RBSGA, NAT/348. 


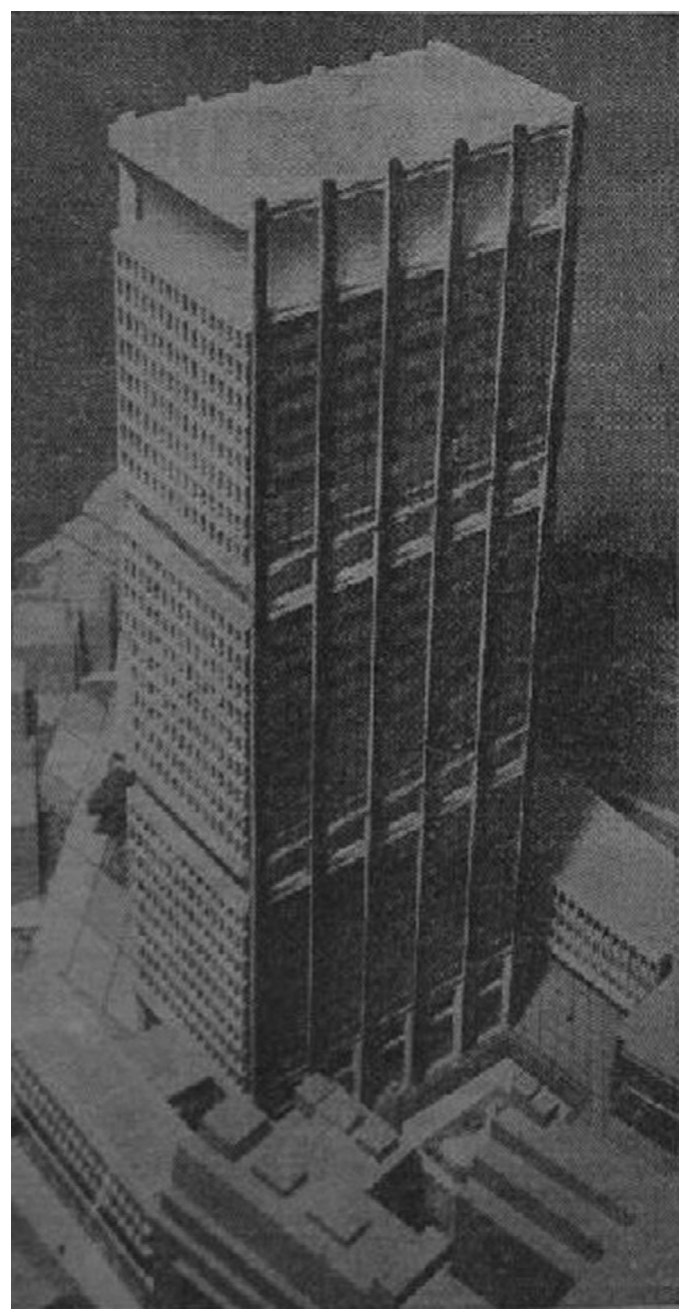

Figure 5 Model of new skyscraper on Gibson Hall (NAT/348, Papers concerning the proposed rebuilding of the Bishopsgate head office of National Provincial Bank Ltd and consequent plans for the NatWest Tower, Evening Standard, 18 February, 1964).

asserted their importance mainly through sheer monumentalism. Moreover, a decision that the City's arguably most important Victorian bank building could be replaced by a skyscraper would have opened the door to the rapid replacement of the City's built heritage by similar office blocks.

However, like most modernist skyscrapers, the planned headquarters faced the problem that the public had no affection for this new architectural style to balance the scales against the loss of much-loved earlier buildings. A few fine examples of modernist skyscrapers were 
developed in other areas of central London-such as the Economist Building (SW1) and Millbank Tower (Westminster)—both employing "podium and plaza" designs to ease congestion on the ground. However, even these did not generate widespread public affection, as evidenced by the Reuben brothers' successful 2016 application to redevelop Millbank, despite it being listed. ${ }^{80}$ The only postwar, tall office building to capture the public imagination was the Post Office Tower, which had a distinctive space-age design that could only be called modernist on a loose definition of the term.

Architects and planners argued that modernism was avant-garde, implying that people would eventually warm to it-but sixty years later there is still no significant evidence of the general public doing so. There were also growing perceptions that comprehensive development was creating urban environments worse than those they replaced. As Gavin Stamp noted, "The intention of the Modern Movement to rebuild from scratch, to create a new world, unleashed a process of comprehensive development, which was really a form of terror. This both discredited the architecture and provoked resistance." ${ }^{\text {81 }}$

National Provincial fell back on the main professional constituency supporting the new style-the architects, carefully selecting one known to be a true believer. ${ }^{82}$ A letter from the selected architect was duly sent to the LCC and the public inquiry into the Gibson Hall demolition. The allusion to modernity was apparent here in the anonymous architect's suggestion that "no other age could have produced this solution." ${ }^{83}$ However, by ignoring public opinion and assuming that economic arguments would ultimately trump objections, the bank had overplayed its hand in the wake of two very high profile historic building demolitions and the run-up to a general election. Bad timing would

${ }^{80}$ Randeep Ramesh, "Zac Goldsmith Received £46,000 Linked to Luxury Flat Developers,” Guardian, May 3, 2016, https://www.theguardian.com/politics/2016/ may/03/luxury-flat-developers-reuben-linked-to-46000-of-donations-to-zac-gold smith; "The Economist Group (Including Office Tower, Residential Block, Former Bank and Podium," Historic England, https://historicengland.org.uk/listing/the-list/ list-entry/1264050.

81 Stamp, "The Art of Keeping One Jump Ahead," 77.

82 One architect was telephoned in advance about giving evidence. As he had "known the City Offices of National Provincial for some 30 years and that considers it to be one of the finest examples of Victorian classical architecture in the City of London," it was decided that evidence from him "would not be helpful." File concerning planning permission for the head office rebuilding project of National Provincial Bank Ltd at Bishopsgate, letter January 29, 1964, RBSGA, NAT/1777/23.

${ }^{83}$ Papers concerning the proposed rebuilding of the Bishopsgate head office of National Provincial Bank Ltd and consequent plans for the NatWest Tower, untitled and dated official document from National Provincial relating to the public inquiry, RBSGA, NAT/348. 
continue to plague National Provincial and its successor NatWest in their further efforts to find satisfactory headquarters accommodation.

\section{The Long-Term Impacts of the Gibson Hall Decision}

The Gibson Hall preservation decision set an important precedent for the prioritization of conservation over maximizing the functionality and economic value of building plots. There were no further demolitions equivalent to the Euston Arch and Coal Exchange. In addition to its value as a precedent for future planning applications, Gibson Hall also acted as an important deterrent to companies from even seeking permission to demolish listed buildings, as they were likely to face severe delays, negative publicity, substantial costs, and only a small chance of a successful outcome. The long-term impact on the banking sector-which had experienced rapid branch network expansion in the Victorian period, often using notable architects-was far-reaching. As Newman noted in 1984, "Probably between ten and twelve per cent of all branches of the major clearing banks are in listed buildings," which restricted the ability of banks to modernize their premises to meet customer and staff requirements. ${ }^{84}$

The potential implications of the decision may account for the press backlash when the planning inquiry decision was announced. For example, the Statist attacked Sir Keith Joseph's decision directly and the "alleged aesthetic virtues of the banking hall." The building was described as a "choice piece of architecture ... [which] symbolises the Victorian age's predilection for wasting space," and it cast doubt on the "genuine architectural merit in National Provincial Bank building." 85 National Provincial, on the other hand, responded more delicately to Joseph's ruling. Vice-chairman Sir Ivan Stedeford (1897-1975) went on the record to say that the "refusal meant a serious delay in the bank's plans to modernise its business as soon as possible.” Their spokesman, in a more formal response, stated that "there were no questions, however, of moving from the present site." 86

The minister for housing had left room for National Provincial to modify and resubmit a plan for a new head office on the plot of land surrounding Gibson Hall. Thus, the stipulation that the original banking hall must be preserved did not discourage the bank from proposing

${ }^{84}$ Newman, Financial Marketing and Communications, 317.

${ }^{85}$ Papers concerning the proposed rebuilding of the Bishopsgate head office of National Provincial Bank Ltd and consequent plans for the NatWest Tower, RBSGA, NAT/348. The Statist, "Banking Victoriana, ” August 14, 1964.

${ }^{86}$ Intelligence Dept., The Times, "City Bank Building to Stay,” August 8, 1964, RBSGA, NAT/348. 
further plans to redevelop the site. Indeed, the bank's architect did not seem too disheartened by the result. National Provincial thus submitted plans to the Court of Common Council of the City of London Corporation. Once again, its actions proved ill-timed.

The election of a Labour government in October 1964 witnessed a substantial shift in ministerial attitudes toward preservation, with the appointment of Richard Crossman as minister of housing and local government. Crossman championed this issue, much to the chagrin of the long-serving permanent secretary, Dame Evelyn Sharp (who was a persistent champion of comprehensive development and other policies pushed by property developers and architects, including highrise municipal housing). ${ }^{87}$ More importantly, on November 4, 1964, Labour's new minister of economic affairs, George Brown, announced an almost complete ban on new office development in London (which became known as the "Brown Ban"), responding to fears of London turning into an office monoculture with congestion that might arise from an ever-growing army of office workers commuting into London. ${ }^{88}$

National Provincial reacted angrily, stating that "the Board [of Trade] had given no reason, apart from pointing out the need for spreading work more evenly throughout the country. The bank was faced with the prospect of carrying on with its head office staff scattered in various buildings." 89 Once again the bank's friends in the press rallied to its defence. The Economist stated that "the bank's case for rebuilding is a strong one, and the refusal of permission to do so is the most striking evidence yet of the authorities' determination to call a halt." The Financial Times sympathized with the bank openly, but negative press reaction had little impact on government policy. ${ }^{90}$

The following years witnessed a further tipping in the balance of public opinion toward preservation. The planned demolition of St. Pancras Station was blocked, thanks to a campaign fronted by John Betjeman, and granted Grade I listed status in 1967. In light of the

87 Pendlebury and Strange, “Centenary Paper,” 361-392; Delafons, Politics and Preservation, 90-94.

${ }^{88}$ Marriott, The Property Boom, 11, 117.

${ }^{89}$ Papers concerning the proposed rebuilding of the Bishopsgate head office of National Provincial Bank Ltd and consequent plans for the NatWest Tower, Report from Parker, Bishop Limited, head office rebuilding, BBC home service, news, August 15, 1965, 6:00 p.m, RBSGA, NAT/348.

${ }^{90}$ It stated that "one can understand why the NPB feels hard done by at the Board of Trade's refusal to allow it to rebuild its head office in the City." Papers concerning the proposed rebuilding of the Bishopsgate head office of National Provincial Bank Ltd and consequent plans for the NatWest Tower, Intelligence Department, Financial Times, Patrick Coldstream, "A succession of checks for the National Provincial Bank,” August 17, 1965, RBSGA, NAT/348. 


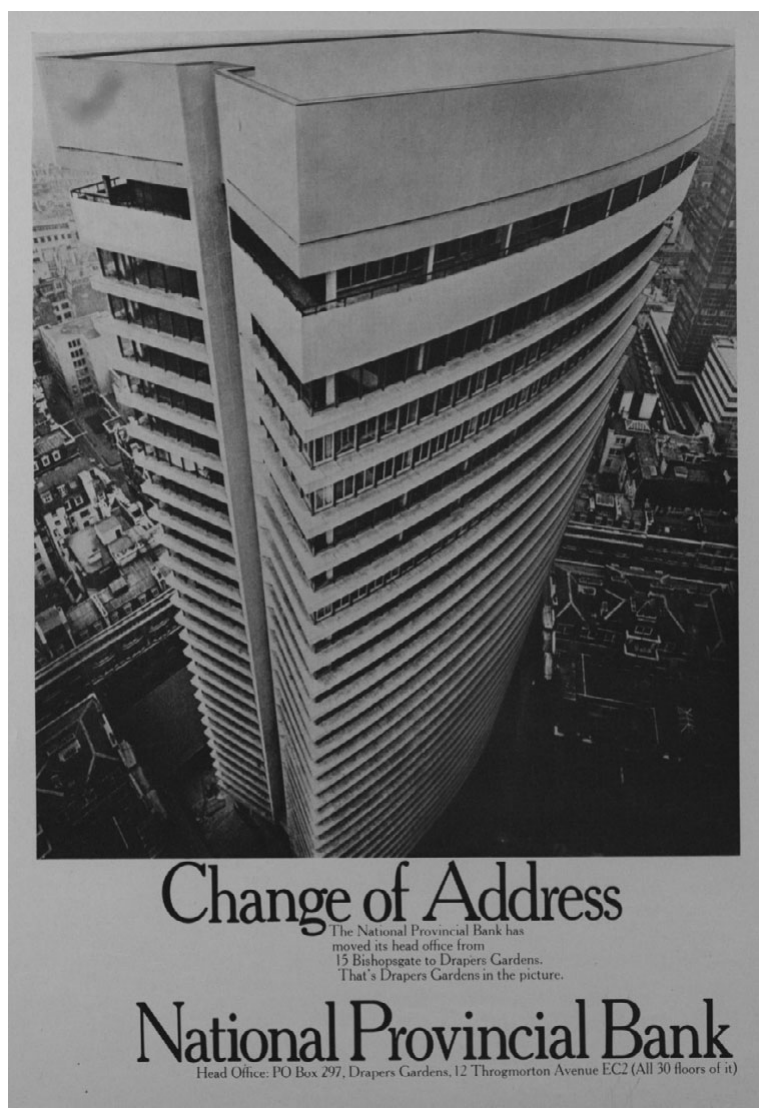

Figure 6 Drapers Gardens advertisement (Illustrated London News, June 03, $1967,16)$.

conservation lobby and the Brown Ban, National Provincial was forced to "mark time" on its plans to redevelop in the "hope that in the next year or so the climate of opinion will change." ${ }^{11}$ However, lacking patience and signs that the climate was changing, the bank actively pursued other options. One was the new building under construction in Drapers Gardens, shown in Figure 6. In December 1965, National Provincial announced that it had negotiated a lease and gave 1966 as their entry date. ${ }^{92}$

No. 7 Drapers Gardens had not been built specifically for the bank but was available imminently. It was also well suited as a distinctively

91 Intelligence Dept., Financial Times, "Natpro Bank Headquarters Rebuilding: Plan to be Kept in Being," August 17, 1965, RBSGA, NAT/348.

92 Intelligence Dept., Financial Times, "Natpro Bank Moving Head Office," December 24, 1965, RBSGA, NAT/348. 
modern headquarters, designed by the prolific modernist commercial architect Richard Seifert, and stood twenty-eight stories high. ${ }^{93}$ National Provincial proclaimed triumphantly that with this move "a new chapter is being written now." 94 The white heat of the 1960s had prompted organizations to look to the future. It was reported that nine floors were to be given over to automation. Even so, the bank remained conscious that it was well behind both American automation methods and the other British banks. The skyscraper was described by the press and in National Provincial's internal documents as the "only ascetically pleasing skyscraper in the City," owing to "its mixture of angles and curves" (an implicit acknowledgment of the general failure of postwar office architecture to connect with either the general public or its patrons). ${ }^{95}$ Similarly, Marriott described Drapers Gardens as one of the few offices built in the City of London during the 1960s that "attempted to break away from the accepted speculative norm." 96 Initiated prior to the Brown Ban, it was one of only a few new London office blocks available at the time and thus commanded a high price. Property developer Harry Hyams "personally bargained with the chairman of the National Provincial and let him Drapers Gardens at the highest rent ever seen in the City, over $£ 5$ a square foot, a rent which turned white the hair of the stockbrokers gossiping in its shadow."97

National Provincial merged with Westminster Bank in 1968, trading under its own name until 1970, when the new institution was renamed the National Westminster Bank (NatWest). The merger moved the bank forward in terms of size-by 1969 NatWest was second only to Barclays among the "Big Four" retail banks regarding market share in deposits and advances, as well as profits. ${ }^{98}$ However, it failed to shed its traditional image of being managed in "a clubby style" and there was a persistent "negative interpretation [which] emphasized how NatWest was consistently lagging behind its competition in adapting to market changes." 99 The process of shedding its old image and some of its history was not swift. Moreover, changing inherited attitudes, business practices, and other outdated elements of

93 Calder, Raw Concrete, 213, 225-227.

94 Illustrated London News, June 3, 1967, 16.

95 Papers concerning the proposed rebuilding of the Bishopsgate head office of National Provincial Bank Ltd and consequent plans for the NatWest Tower, Stock Exchange Gazette, March 25, 1966, RBSGA, NAT/348.

96 Marriott, The Property Boom, 74.

97 Ibid., 118.

98 Ackrill and Hannah, Barclays, 201, 204.

99 Rogers, The Big Four British Banks, 148-149. 
its business model was far more challenging than simply moving to an ultramodern headquarters. ${ }^{100}$

Ironically, Drapers Gardens itself was demolished in 2007, despite a campaign to grant the building listed status-even what was considered to be an unusually good example of midcentury office architecture could not command sufficient public support for preservation. National Westminster had long since moved to a purpose-built new head office, the NatWest Tower, in 1980 (also designed by Seifert); it was London's tallest skyscraper from its construction to 1990.

NatWest Tower provided a new head office for the merged bank and was intended to "crown" the City, according to Pawley. ${ }^{101}$ From above, the tower resembled the National Westminster Bank logo. A glossy color brochure produced by the bank, proclaimed that

National Westminster Tower is the second tallest occupied building in Europe. It soars 600 feet above the surrounding streets.... The design was chosen after models of alternatives were placed on display in the Royal Exchange and members of the public were asked to indicate their preferences. We are sure the right choice was made and believe public opinion generally endorses our pride in this significant contribution to the architecture of the city $[$ sic $] .{ }^{102}$

The element of public consultation in the choice of design demonstrates the bank's awareness of the need to gain public approval for its new headquarters, having learnt from the public opposition to the proposed demolition of Gibson Hall.

The central core of the tower was made of reinforced concrete, surrounded by three linked wings that contained office accommodation for 2,500 staff. The wings were faced with stainless steel ribs and did not reach to ground level, but instead they were supported at the base by a "massive reinforced cantilever." Queen Elizabeth II opened the tower in 1981, and for a while it was the tallest building in Britain. ${ }^{103}$

Yet NatWest Tower also had a troubled history. Objections to the initial designs and to the proposed height of the tower, followed by public consultations, delayed construction, which started in 1970 and was not completed until 1981. Deregulation of the stock exchange in

\footnotetext{
${ }^{100}$ For discussion of the difficulties faced in changing key elements of business models that served them well in their earlier history, see Christensen, Bartman, and van Bever, "The Hard Truth About Business Model Innovation," 30-40.

101 Pawley, Terminal Architecture, 54-55.

102 "National Westminster Tower" (Nationals Westminster Bank PLC), n.d., n.p, RBSGA, NAT/814.

103 "National Westminster Tower" (Nationals Westminster Bank PLC), RBSGA, NAT/814.
} 
1986 and the financial crash of 1987, followed by economic recession and a commercial property market slump, meant that the tower quickly became outdated as a modern bank headquarters. ${ }^{104}$ It had become technically obsolete in terms of efficiently accommodating modern electronic workstations, cables, ventilation, and open trading floors. A 1992 terrorist bomb at the Baltic Exchange then damaged the tower, and further, more serious damage was caused by another bomb in 1993. London's chief planning officer, Peter Rees, called for the tower's demolition, stating that it was “inefficient by today's building standards: National Westminster Bank keeps it as a status symbol. The City will need another landmark symbol." 105 This view illustrated the dual nature of the bank headquarters: functional suitability to house modern, rapidly changing banking operations combined with the ability to signal status and power. NatWest refurbished the tower rather than demolish it; the building was renamed the International Financial Centre, and it reopened in 1997. ${ }^{106}$

Gibson Hall was also damaged in the 1993 bombing and required renovation. It was converted into an events venue, obtaining a licence to host weddings in $1997 .{ }^{107}$ NatWest Tower was eventually sold in 1998 for $£ 226$ million, along with four older buildings including Gibson Hall. The bank itself leased back-office space in the tower on a market basis. ${ }^{108}$ The tower was renamed Tower 42 and was redeveloped with office space throughout, restaurants at the top to capture views, and retail space at the base. It was then sold again in 2011 to a South African property investor for $£ 285$ million. ${ }^{109}$

The movement of head offices from Bishopsgate to Drapers Gardens and then to NatWest Tower leads to consideration of the concept of obsolescence, recognized in architecture as resulting from "changing technology, economics, and land use, in which the new would inevitably outperform and devalue the old." ${ }^{110}$ Abramson has argued that the concept of obsolescence entered U.S. public consciousness in the 1920s and was accelerated by the consumer culture of the 1960s, when it became a global phenomenon. ${ }^{111}$ He goes on to assert that architectural obsolescence "has come to be understood as a general condition of

104 Pawley, Terminal Architecture, 56.

105 Kattoulas, "The Leaning Tower of Bishopsgate."

106 “NatWest Tower Reopens," The Banker, vol, 147 (1997) no. 856, 5.

107 "Get Knotted," Financial Times, September 4, 1997.

108 George Graham, "Nat West Tower Sold for £226m," Financial Times, July 18, 1998, 21.

109 Ed Hammond, “Kirsh Poised to Scale Tower 42," Financial Times, November $19,2011$.

110 Abramson, Obsolescence: An Architectural History, 3.

111 Ibid., 3. 
change in architecture and cities as a whole-a relentless, universal, impersonal process of devaluation and discard." 112

Gibson Hall had been built to assert National Provincial's organizational identity and it was built to last. Indeed, the bank resided there for one hundred years. In the changing postwar financial world, such longevity of construction became problematic. By the 1950s, it was more beneficial for the bank to move to a modern office block to house the technology required for banking. However, the bank did not look for a faceless and functional skyscraper that it could disregard if it, in turn, became obsolete. Instead, it sought to construct a new, purpose-built head office to symbolize its modern identity. However, the subsequent decades witnessed a further intensification of obsolescence, as evidenced by the short life of Drapers Gardens and the even shorter life of NatWest Tower as a bank headquarters.

In 2006, the Financial Times described skyscrapers such as NatWest Tower as "the drab pinnacles stuck up a generation ago." 113 Such a scathing assessment harks back to National Provincial's campaign to devalue their Victorian headquarters (though this time it echoed popular perceptions). Given the pace of change in banking, it would have been less problematic for NatWest to do away with the notion of head office as status symbol (such as the NatWest Tower) in favor of more pragmatic and expendable buildings. However, despite typical office lifespans of under forty years, bank headquarters towers such as those in Canary Wharf that house HSBC and Barclays are still instantly recognizable and clearly branded. This may reflect the low risks of preservation pressure, given that there has never been a strong public campaign to preserve any post-1945 British commercial skyscraper.

\section{Meeting the Conflicting Aims of Urban Preservation and a Modern Financial Sector}

The 1970s witnessed a swelling of the ranks of (hitherto largely elitistled) preservationists by left-wing and environmentalist groups, brought together in part by the conservation environmentalism of Jane Jacobswho correctly foresaw the serious economic, social, and crime costs of comprehensive redevelopment aimed at converting established communities into a mix of high-rise buildings and fast roads. ${ }^{114}$ This new

112 Ibid., 5.

113 "Glass and Steel Reflect the Irresistible Winds of Change," Financial Times, March 31, 2006.

114 Jacobs, The Death and Life of Great American Cities; Jacobs, The Economy of Cities. 
alliance coalesced most notably around plans to radically redevelop London's Covent Garden district, which were successfully blocked following a massive protest campaign. ${ }^{115}$ Meanwhile, a series of highprofile criminal trials during the 1970s highlighted the extensive (arguably ubiquitous) corruption underlying the awarding of comprehensive development planning permissions and local authority tower block housing contracts, further damaging the public image of the property development industry. ${ }^{116}$

During the 1980s, the conflicting pressures of a powerful conservation lobby and City firms' need to expand and update their accommodation standards intensified in the run-up to the 1986 financial deregulation “Big Bang.” The Corporation of London's ill-timed 1984 Draft Plan for the City of London accentuated the hostility of City firms to the Corporation's planning stance. ${ }^{117}$ The plan reflected not only the needs of building conservation, but also the protection of the City's nonservice industries such as the fur trade and Fleet Street. Therefore, it drew howls of protest from City firms, which demanded tall buildings with large floor plans, column-free trading floors, and high room heights to accommodate cabling and air-conditioning ducts. ${ }^{118}$

City firms began looking eastward for alternative locations-to the Canary Wharf development on London's Isle of Dogs, together with other areas on the City's eastern fringes. The City Corporation thus took a sharp U-turn, with a new May 1986 plan that placed much more emphasis on City office development while still preserving key historic buildings. ${ }^{119}$ The City's allowable office space was increased by 11 million square feet (equivalent to a potential office-space increase of about 20 percent) through adjusting maximum plot ratios and relaxing its previously strong conservation measures. ${ }^{120}$

However, by this time plans were underway to develop Canary Wharf as a new financial hub-along the lines of Paris's successful transformation of La Défense from a declining industrial area to a modern financial center. Unencumbered with the delays inherent in planning inquiries (it had been designated as an "Enterprise Zone," removing virtually all planning constraints), plans for Canary Wharf were at an advanced stage. ${ }^{121}$ Despite teething problems (especially during the 1989-1992 property crash), ${ }^{122}$ Canary Wharf finally gave

\footnotetext{
115 Delafons, Politics and Preservation, 108-109.

116 Scott, "Friends in High Places," 1-21.

117 Marmot and Worthington, "Great Fire to Big Bang," 219.

118 Ibid., 220-221.

119 Ibid., 220-221.

120 Scott, The Property Masters, 223-225.

121 Ibid., 218-219.

122 Pawley, Terminal Architecture, 66.
} 
the clearing banks what they had long wanted, a free hand to build huge skyscrapers that would illustrate their economic power and prestige through sheer monumentalism. Completion of the Jubilee line extension, development of City Airport, and investment in the Docklands Light Railway ensured that this new financial district was a success. In contrast, City office projects that entailed tearing down historic buildings faced continuing barriers, as demonstrated by one eventually successful project-No.1 Poultry at Bank junction. Bank junction sits at the heart of the historic City, immediately bounded by the Bank of England, Mansion House, and the Royal Exchange buildings. Redevelopment proposals for No.1 Poultry were first muted in the 1960s, sparking a development battle that lasted some thirty years. Most developers would have long since given up, but Peter Palumbo's personal commitment to bringing an eighteen-story landmark Mies van der Rohe tower block to the City eventually achieved success in the 1990s after two public inquiries and referrals to the secretary of state and the law lords.

No. 1 Poultry was completed in 1997, by which time Palumbo senior had died. ${ }^{123}$ It became the youngest building to receive Grade II listing in 2016. ${ }^{124}$ Palumbo's Pyrrhic victory demonstrates the enduring strength of conservation pressures. By 1997 the originally avant-garde design looked out-of-date, as did Polumbo's development strategy (given the oversupply of property in the wake of the 1989-1992 property slump). Developers lacking his almost unbusinesslike determination to bring his project to fruition would most likely see this episode as a cautionary tale rather than the green light for demolishing historic City buildings. ${ }^{125}$ The Corporation of London has continued to defend swathes of the historic City. ${ }^{126}$ Yet the City had to balance its uniqueness as a historical global financial center on the one hand and, on the other, facilitate the expansion and progression of banks and financial service companies within it. Competition from other financial centers such as New York and Frankfurt constitute an ever-present threat, not to mention Docklands.

\section{Conclusions}

The history of National Provincial/NatWest's headquarters planning shines a light on the relationship between flagship corporate buildings,

123 Palumbo's son saw through the development. Jacobs, Edge of Empire, 43-46.

124 Hugo Greenhalgh, "Earning Its Stripes Salmon-Pink Youngster Gains Grade II* Listing," Financial Times, December 3, 2016.

125 Jacobs, Edge of Empire, 55-57.

126 Ibid., 47. 
brand identity, conservation, and the trend of accelerating functional obsolescence for corporate offices. When office blocks emerged as a distinct building form in the mid-nineteenth century, the buildings they replaced were typically residences and were rarely considered "distinctive." Firms thus sought to build new London headquarters as solid and decorative as the Roman buildings that inspired them, blissfully unaware that when the time came for demolition the public might object.

By the 1960s, the unnecessary destruction of two important London landmarks (both, ironically, due to public sector developments) created a hostile climate for the redevelopment of prominent historic buildings that were now regarded as much more important-in part because of the massive destruction of City property during World War II. The banks were essentially bystanders in the earlier failed conservation campaigns that had reinforced and empowered the urban preservation movement. However, in the absence of tight planning controls, their development requirements (together with those of other City firms) would almost certainly have swept away most of the remaining historic City, replacing it with faceless, homogenous, and ephemeral skyscrapers.

The Gibson Hall decision and the precedent it created had effectively introduced a strong preservation regime for existing buildings, but had relatively little impact on tightening up Britain's weak aesthetic control over new building design (especially outside historic towns and districts). Thus, the wider community had substantial "negative power" to preserve buildings of considerable architectural merit (through the planning process, protests, and public inquiries), but weak "positive power" to demand high aesthetic standards for new office buildings. ${ }^{127}$ Meanwhile, developers were deterred from choosing distinctive building designs, as this increased the risk that society's negative power might block their eventual demolition. Therefore, the urban preservation movement had saved Britain's architectural past, but had further intensified developers' incentives to create a banal architectural future.

Conservation pressures helped to create a new attitude among banks and other financial institutions seeking headquarter buildings, with architectural distinctiveness being regarded as a risk rather than a virtue-especially in an era of accelerating obsolescence in which new buildings could be expected to have less than half the lifespan of Gibson Hall. The banks ultimately solved their modernization problem through a combination of outbidding other potential occupants of 3-19.

127 Rus, "Positive and Negative Power: Thoughts on the Dialectics of Power," 
those modern buildings and cleared sites that were available in the City; moving eastward to areas less constrained by planning controls and historic buildings; and, crucially, further embracing a building design ethos that would guarantee minimal public opposition to eventual demolition, given that-more than half a century after its widespread adoption-the public still shows no signs of warming to modernist office architecture. The net result is a "throwaway" headquarters architectural style, incurring minimal risk of future conservation battles, as-in the eyes of the public-there is nothing to conserve.

Bibliography of Works Cited

Books

Abramson, Daniel M. Building the Bank of England: Money, Architecture, Society 1694-1942. New Haven, CT: Yale University Press, 2005.

- Obsolescence: An Architectural History. Chicago: University of Chicago Press, 2017.

Ackrill, Margaret, and Leslie Hannah. Barclays: The Business of Banking, 16901996. Cambridge, UK: Cambridge University Press, 2001.

Baedeker, Karl. London Und Umgebungen. Leipzig: Publisher of Karl Baedeker, 1894.

Belfoure, Charles. Monuments to Money: The Architecture of American Banks. Reprint, Jefferson, NC: Mcfarland, 2011.

Booker, John. Temples of Mammon: The Architecture of Banking. Edinburgh: Edinburgh University Press, 1992.

Brooks, Michael W. John Ruskin and Victorian Architecture. London: Thames \& Hudson Ltd, 1991.

Calder, Barnabas. Raw Concrete: The Beauty of Brutalism. London: William Heinemann, 2016.

Delafons, John. Politics and Preservation: A Policy History of the Built Heritage, 1882-1996. London: E \& FN Spon, 1997.

Esher, Lionel. A Broken Wave: The Rebuilding of England, 1940-1980. London: Allen Lane, 1981.

Jacobs, Jane. The Death and Life of Great American Cities. London: Cape, 1962.

- The Economy of Cities. London: Cape, 1970.

- Edge of Empire: Postcolonialism and the City. Abingdon, Oxon: Routledge, 1996.

Kynaston, David. The City of London. Vol. 1, A World of Its Own, 1815-1890. London: Pimlico, 1995. 
The City of London. Vol. 4, A Club No More, 1945-2000. London: Pimlico, 2002.

Marriott, Oliver. The Property Boom. London: Abingdon Publishing, 1989.

Newman, Karin. Financial Marketing and Communications. Eastbourne, UK: Holt, Rinehart and Winston, 1984.

Orbell, John, Alison Turton, and L. S. Pressnell. British Banking: A Guide to Historical Records. Studies in British Business Archives. Aldershot, Burlington, ON: Ashgate, 2001.

Pawley, Martin. Terminal Architecture. Essays in Art and Culture. London: Reaktion Books, 1998.

Reed, Richard. National Westminster Bank: A Short History. London: privately published, 1989.

Rogers, David. The Big Four British Banks: Organisation, Strategy and the Future. Basingstoke, UK: Palgrave Macmillan, 1999.

Scott, Peter. The Property Masters: A History of the British Commercial Property Sector. Abingdon, UK: Routledge, 2015.

Stamp, Gavin, and Colin Amery. Victorian Buildings of London, 1837-1887: An Illustrated Guide. London: Architectural Press, 1980.

Ward-Jackson, Philip. Public Sculpture of the City of London. Vol. 7 of Public Sculpture of Britain. Liverpool: Liverpool University Press, 2003.

\section{Articles and Chapters in Books}

Barnes, Victoria, and Lucy Newton. "How Far Does the Apple Fall from the Tree? The Size of English Bank Branch Networks in the Nineteenth Century." Business History 60, no. 4 (May 19, 2018): 447-473. https://doi.org/10.1080/ 00076791.2017.1323883.

—. "Symbolism in Bank Marketing and Architecture: The Headquarters of National Provincial Bank of England.” Management \& Organizational History 14, no. 3 (July 3, 2019): 213-244. https://doi.org/10.1080/17449359.2019. 1683038.

Black, Iain S. "National Provincial Bank Building in North-East England in the Later Nineteenth Century.” Durham Archaeological Journal 17 (2003): 63-82.

. "Rebuilding 'The Heart of the Empire': Bank Headquarters in the City of London, 1919-1939.” Art History 22, no. 4 (November 1999): 593-618. https://doi.org/10.1111/1467-8365.00177.

- "Spaces of Capital: Bank Office Building in the City of London, 18301870.” Journal of Historical Geography 26, no. 3 (2000): 351-375. https:// doi.org/10.1006/jhge.2000.0234.

Christensen, Clayton M., Thomas Bartman, and Derek van Bever. "The Hard Truth About Business Model Innovation." MIT Sloan Management Review 58(1) (2016): 30-40.

Cottrell, P. L., and Lucy Newton. "Banking Liberalization in England and Wales, 1826-1844." In The State, the Financial System and Economic Modernization, edited by Richard Sylla, Richard Tilly, and Gabriel Tortella, 75-117. Cambridge: Cambridge University Press, 1999. 
Dovey, K. "Corporate Towers and Symbolic Capital." Environment and Planning B: Planning and Design 19, no. 2 (1992): 173-188. https://doi.org/ 10.1068/b190173.

Earl, John. "London Government: A Record of Custodianship.” In Preserving the Past: The Rise of Heritage in Modern Britain, edited by Michael Hunter. Stroud, UK: Alan Sutton, 1996.

Frandsen, Ann-Christine, Tammy Bunn Hiller, Janice Traflet, and Elton G. McGoun. "From Money Storage to Money Store: Openness and Transparency in Bank Architecture." Business History 55, no. 5 (July 1, 2013): 695-720. https://doi.org/10.1080/00076791.2012.715282.

Kattoulas, V. “The Leaning Tower of Bishopsgate.” Euromoney 293 (1993): 11. Marmot, Alexi Ferster, and John Worthington. "Great Fire to Big Bang: Private and Public Designs on the City of London.” Built Environment 12, no. 4 (1986): 216-233.

Pendlebury, John, and Ian Strange. "Centenary Paper: Urban Conservation and the Shaping of the English City." The Town Planning Review 82, no. 4 (2011): 361-392.

Rus, Veljko. "Positive and Negative Power: Thoughts on the Dialectics of Power." Organization Studies 1, no. 1 (January 1980): 3-19.

Schultz, Majken, and Mary Jo Hatch. "The Cycles of Corporate Branding: The Case of the LEGO Company." California Management Review 46, no. 1 (October 1, 2003): 6-26. https://doi.org/10.2307/41166229.

Scott, Peter. "Friends in High Places: Government-Industry Relations in Public Sector House-Building during Britain's Tower Block Era." Business History 62, no. 4 (2020): 1-21. https://doi.org/10.1080/00076791.2018.1452913.

Scott, Peter M., and James T. Walker. "'Stop-Go' Policy and the Restriction of Postwar British House-Building.” The Economic History Review 72, no. 2 (2019): 716-737. https://doi.org/10.1111/ehr.12700.

Smith, Otto Saumarez "Central Government and Town-Centre Redevelopment in Britain, 1959-1966." The Historical Journal 58, no. 1 (March 2015): 217-44. https://doi.org/10.1017/S0018246X14000077.

Stamp, Gavin. "The Art of Keeping One Jump Ahead: Conservation Societies in the Twentieth Century." In Preserving the Past: The Rise of Heritage in Modern Britain, edited by Michael Hunter. Stroud, UK: Alan Sutton, 1996.

Suddaby, Roy, William M. Foster, and Chris Quinn Trank. "Rhetorical History as a Source of Competitive Advantage." In The Globalization of Strategy Research, edited by Joel A. C. Baum and Joseph Lampel, 147-173. Bingley, UK: Emerald, 2010.

Summerson, John. "The Victorian Rebuilding of the City of London." The London Journal 3, no. 2 (November 1, 1977): 163-185. https://doi.org/ 10.1179/ldn.1977.3.2.163.

Waterhouse, Paul, and John Elliott. "Gibson, John (1817-1892), Architect." In Oxford Dictionary of National Biography. Oxford University Press, September 23, 2004. Accessed May 3, 2020. https://www.oxforddnb.com/ view/10.1093/ref:odnb/9780198614128.001.0001/odnb-9780198614128-e10626. 
Vik, Pål. “'The Computer Says No': The Demise of the Traditional Bank Manager and the Depersonalisation of British Banking, 1960-2010.” Business History 59, no. 2 (February 17, 2017): 231-249. https://doi.org/10.1080/ 00076791.2016 .1177024$.

\section{Archival Sources}

London Metropolitan Archives, London, United Kingdom The National Archives, Kew, United Kingdom

Royal Bank of Scotland Group Archives, Edinburgh, United Kingdom (RBSGA)

Newspapers and Magazines

The Banker

Bankers' Magazine

The Builder

City Press

Daily Telegraph

Evening Standard

The Financial Times

Gentleman's Magazine

The Guardian

Illustrated London News

Investors Chronicle

The Statist

Stock Exchange Gazette

Sunday Times Business News

The Times 